consist of prints, transparencies and stereoscopic work, in monochrome and colour. A special foature of this year's Exhibition will be a panel of prints by Mr. Oliver Pike, an honorary Fellow of the Society, who this year has reached his eightieth year and his fiftieth year of membership of the Society. After the London showing, the whole Exhibition is to go to Exeter, where it will be shown during January 6-Fobruary 1, in the Royal Albert Memorial Museum.

\section{Plant Breeders' Rights}

A JorNT announcement by the agricultural departments in the United Kingdom says that the Committee on Transactions in Seeds, which is inquiring into the rights and remuneration of breeders of new varieties of plants, is prepared to receive written evidence and views on the subject of the inquiry. These should be addressed to the Secretary of the Committee, 1/3 St. Andrew's Place, Regent's Park, London, N.W.1, to reach him before December 31 .

\section{University News: Queen's University, Belfast}

DR. H. B. HENBest, reader in organic chemistry at King's College, London, has been appointed to the chair of organic chemistry at the Queen's University, Bolfast, in succession to Prof. R. A. Raphael.

London

DR. P. T. MATThews, lecturer in the University of Birmingham, has been appointed to the University readership in applied mathematics tenable at the Imperial College of Science and Technology.

\section{Sheffield}

THE following appointments in the University of Sheffield are announced : P. H. Blundell, as director of the Electronic Computation Laboratory; Dr. B. Stevens, as lecturer in physical chemistry; M. S. Clements, as lecturer in civil engineering; Dr. Russell Brown, as lecturer in electrical engineering. The following appointments to fellowships have also been made: C. J. Edmonds, to the Boots research fellowship for work in the Department of Pharmacology and Therapeutics; D. J. Williams, to the C. H. Desch research fellowship in metallurgy; and P. L. Chambers, to the John Stokes research fellowship to be held in the Department of Physiology.

\section{Announcements}

Mr. E. J. MANN, formerly assistant director of the Commonwealth Bureau of Dairy Science and Technology, has been appointed director of the Bureau. He succeeds Mr. A. W. Marsden, who left the Bureau in July 1957 in order to take up his new appointment as organizing secretary of the Fifteenth International Dairy Congress.

ThE Reith Lectures for 1957, entitled "Russia, the Atom and the West", will be given by George F. Kennan, professor of history at the Institute for Advanced Study in Princeton and leading American historian of Soviot Russia. This is the first time the Reith Lectures have doalt with the immediate problems of international relations. The lectures will be broadcast on successive Sunday evenings in the B.B.C. Home Service at $9.15 \mathrm{p} . \mathrm{m}$. The first is on November 10.
A BANQuet to celebrate the golden jubilee of the Royal College of Surgeons of England will be held at Lincoln's Inn Fields, W.C.2, on November 12. H.R.H. the Duke of Edinburgh will be present.

A meeting, organized jointly by the Acoustics Group of the Physical Society and the NorthEastern Branch of the Institute of Physics, is to be held at Newcastle on Tyne during November 15-16 on the subject of "Flow Noise". Further information can be obtained from the Secrotary, Physical Society, 1 Lowther Gardens, Prince Consort Road, London, S.W.7.

A sympostume on "Vacancies and other Point Defects in Metals and Alloys" is being arranged by the Metals Physics Committee of the Institute of Metals to be held at Harwell during December 9-10. Further information can be obtained from the Secretary, Institute of Metals, 17 Belgrave Square, London, S.W.1.

A TwO-DAY meeting on water pollution in the iron and steel industry will be held by the Iron and Steel Engineers Group at Church House, Westminster, London, S.W.1, during December 11-12. The meeting will be open to all those interested whether they are members of the Iron and Steel Institute or the Iron and Steel Engineers Group or not.

A CONFEREnCE on "The Band Theory of Metals and the Structure of the Fermi Surface", organized by the Physical Society, will be held at the Imporial College of Science and Technology, London, during December 19-20. There will be four sessions on: theoretical aspects of the band structure of metals; experimental results related to band structure; experimental examination of the Fermi surface ; and the Fermi surface and related topics. There will be a limited amount of accommodation available. Nonmembers may attend the conference on payment of a fee of one guinea. All inquiries should be addressed to the Physical Society, 1 Lowther Gardens, Prince Consort Road, London, S.W.7, marked for the attention of Miss Miles.

A CONFERENCE, organized by the Institute of Fuel, on "Science in the Use of Coal" will be held in Sheffield during April 15-17, 1958. There will be six sessions : "Physies and Chemistry of Coal"; "Coal Preparation and Breakage"; "Coal Carbonization" ; "Combustion and Gasification"; "Reactivity of Cokes and Chars"; "General Discussion". Brief opening surveys will be presented at the first five sessions. Advance copies of these will be supplied to authors who intend to submit communications. Further information can be obtained from the Secretary, Institute of Fuel, 18 Devonshire Street, Portland Place, London, W.I.

Erratum. Dr. K. Mendelssohn writes: "My attention has been directed to the fact that in my article on the Russian Low Temperature Conference (Nature, 180,$460 ; 1957$ ) I omitted to mention that two observers, one from Poland and one from Hungary, had also attended. They were not low temperature physicists but hopod to initiate this type of work in their respective countries. Omitting their presence from the list of foreign visitors may give rise to the misinterpretation that I have considered their countries as parts of the U.S.S.R.". 